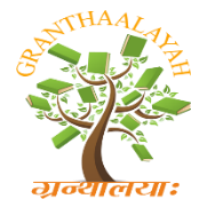

INTERNATIONAL JOURNAL OF RESEARCH GRANTHAALAYAH

A knowledge Repository

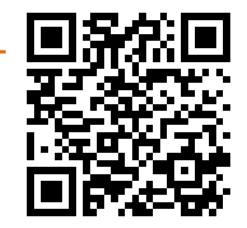

Management

\title{
SMART MUNICIPAL SOLID WASTE MANAGEMENT
}

\author{
Ashwini Patil *1, Swati Jha ${ }^{2}$, Uma Kumari ${ }^{3}$, Surekha KS ${ }^{4}$ \\ *1, 2, 3, ${ }^{4}$ Department of E\&Tc, AIT, Pune, India
}

\begin{abstract}
Municipal Solid Waste generated by India in urban areas is 62 million tonnes. Only $70 \%$ of the total waste is collected and $20 \%$ is treated. Most of the solid waste is dumped in landfill sites. This paper targets the reduction in the size of the solid, particularly wet waste. Similar problems have been tackled in other parts of the world. We propose a solution that fits the Indian context. The key idea of Smart Municipal Solid Waste Management system (SMSWM) is to allocate a weekly garbage limit per household in a residential society. The DSS (Decision Support System) designed for this purpose allows the authenticated user to access the smart dustbin. The smart dustbin is equipped with the electronic circuitry where the weight of the garbage in the bin is measured and the value is updated in the database. The database of the families will be created and maintained by the municipality. A web portal gives the involved people and authorities access to the related information. A house is penalized for every kilogram more than the allotted garbage weight limit. Further enhancements are explored. Thus, the residents are incentivized to produce lesser waste.
\end{abstract}

Keywords: Waste Management; Wet Waste; Weight of the Garbage; Database; Electronic Circuitry; Garbage.

Cite This Article: Ashwini Patil, Swati Jha, Uma Kumari, and Surekha KS. (2020). "SMART MUNICIPAL SOLID WASTE MANAGEMENT." International Journal of Research Granthaalayah, 8(4), 127-132. https://doi.org/10.29121/granthaalayah.v8.i4.2020.17.

\section{Introduction}

Municipal authorities provide solid waste management as a basic service [1,2]. This helps to keep cities clean. In most of the situations, the system is poorly handled. The cities are not well equipped in the effective handling of solid waste. This has resulted in open dumping, burning of solid waste. This is a dangerous health hazard and even spread infectious diseases.

Waste management is a very serious issue, especially in developing countries. As shown in fig. 1, the untreated urban waste will cause environmental pollution. The waste generated increases due to population growth. The municipalities have to develop recycling centres locally instead of a single system which is located at a central place. A system of waste separation requires more types of bins and containers. To improve collection efficiency [3], a suitable methodology needs to be 
adopted. In this paper, we have proposed an IoT based smart waste management system that keeps a check on the waste management in cities.

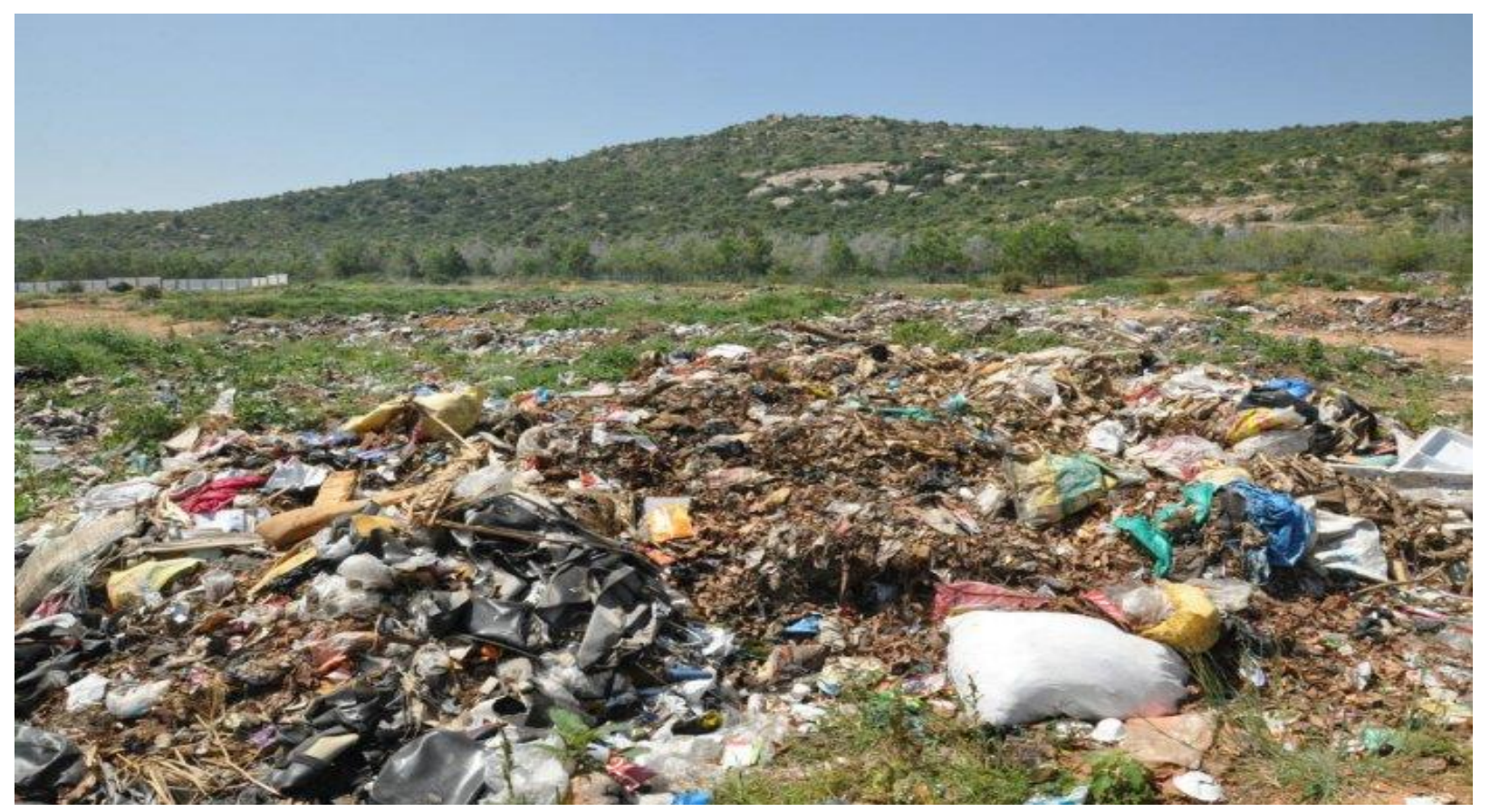

Figure 1: Untreated waste in urban areas

Prakash et.al [4] proposed a real time waste management system. In this system, it is proposed to use multiple dustbins located throughout the city or the Campus. An Embedded device is used to track the level of the garbage bins. Chitluri Sai Srikanth et. al [5] proposed a "sharp Garbage Bin" and is used to alert the individual when the garbage bin is full. Krishna Nirde et.al proposed [6]a system to monitor the status of dustbins using wireless technology. Shamin N et.al [7] proposea sensor-based detection system for waste separation. J.C.S. Carvalho et. al present [8] the INOSHARE framework, which provides the best use of existing resources on a shared sensor and actuator network. This system enables users to create and supervise their applications remotely. Ayesha Habib proposed [9] a tag-based system for sensing applications.

KodwoMiezahet.al proposed [10] a system for a particular region. Some of the parameters collected are per capita of waste, sorting, separation etc. S.Loganayagi et. al [11] proposed an Internet of Things based system which permits the municipal corporations to supervise the dustbin status over web server remotely and maintain the cities clean.

The system described in the literature survey shows continuous efforts by the researchers in the area of waste management. However, the waste management system needs to be enhanced in terms of keeping the city clean. The main objective of the proposed system is to limit the garbage usage by the household. A house is penalized for additional garbage generated. Further improvements in the proposed system is to give incentives to the household generating lesser garbage as compared to the set limit. An IoT based system is proposed to make use of the cloud for data analysis and further improvements in the area. 


\section{Materials and Methods}

The hardware and software requirements are listed below:

\section{Hardware Requirements:}

1) Raspberry Pi 3

2) Load Cell and Driver

3) LCD

4) Motor

5) Motor Driver

\section{Software Requirements}

Requirements for using and accessing the raspberry pi:-

1) Raspbian Buster Full OS

2) Win32 Disk Imager

3) Advanced IP Scanner

4) MobaXTerm Application

The current garbage level is reset weekly for all the houses by the municipal corporation when the garbage of the previous week is collected. A user, on any given day of the week, comes to the bin area with the garbage, authenticates himself in order to dump the garbage into his allocated bin. The load cell measures the new garbage level in the bin and sends this data to the RaspberryPi. The Pi then updates the 'current garbage level' field for that bin number with the new value received from the corresponding loadcell.

The functional block diagram is shown in Fig. 2

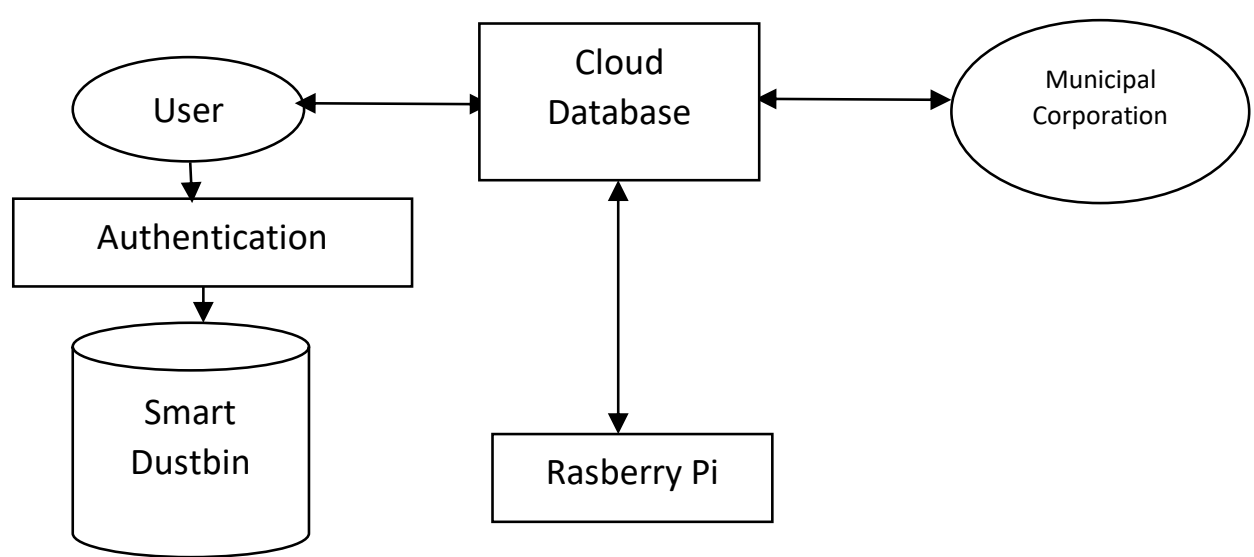

Figure 2 : Functional block diagram

The current level for the particular house number is also checked against a threshold level, in order to see if it is exceeded. If yes, then a fine is charged on each additional kilogram. The user can login to the system to see his current remaining limit so that he can check his garbage production level for the week. The user is alerted when his weekly threshold level is reached. The municipal corporation is alerted when the bins are full so that the garbage can be collected. 


\section{Results and Discussions}

Some of the important points considered for the implementation are listed below:

1) The Population of India: 137 crore

2) Percentage of population living in urban areas: $27 \%$

3) Total number of people living in urban areas: 37.7 crore

4) Total waste generated by urban population: 6.2 crore tonnes of municipal solid waste per year

5) Non-recyclable waste :(70\%) 4.3 crore tonnes (collected waste)

6) Recyclable waste:(20\%) 1.19 crore tonnes (treated)

7) The Total amount of waste generated by per person: 450 gm per person per day [12]

8) New permitted allowed waste generation capacity: 200 gm per person per day

9) Waste generated by a family of size $x$ in one week: $x^{*} 200 * 7$. Let $x$ be 5 , then $7 \mathrm{~kg}$ per week.

10) Amount of waste reduction in whole year: $(15.75-7) \mathrm{kg}=8.75 \mathrm{~kg}$ i.e. $55 \%$.

Taking note of the importance of waste segregation in the entire solid waste treatment process [13][14], the idea can be extended to allocate 2 bins per household and accordingly, separate limits can be put for each of those bins: one for the biodegradable waste and the other for the nonbiodegradable waste.

1) Implementation at society level as smart city's urban waste management system.

Based on the size of the family and the number of families in the society, the weekly maximum limit will be issued by the municipal corporation. This will help in better traffic control of the garbage along with this, the system will keep a check on the amount of garbage produced by the urban households.

2) Implementation at the industrial level.

Depending upon the type of industry or the business firm, the system will be designed for the same. This method will not only allow the municipal corporation to keep track of all the garbage produced but will also help them to prepare future plans and make adequate arrangements for the disposal of the garbage even before its produced.

3) Areas where garbage monitoring is important such as in space stations.

If we can collect data i.e the average amount of garbage produced by the astronauts during their research in space stations which includes the used foodstuff, paper and other miscellaneous items, we may future plan for its disposal rather than dumping in the space.

The advantages and disadvantages of the system are listed.

\section{Advantages}

1) Reduces the amount of waste generated at the base level and hence results in lesser waste that requires treatment.

2) The system can be designed for asociety based implementation or industrial waste generation also. It has great scope in the field of reduction of waste generation at various levels in urban spaces.

3) The collected penalty money can be added to the budget allocated for waste treatment, and can then be used towards advanced waste treatment techniques. 
4) The load of garbage disposal is now shared between the authorities and the common public, making waste a responsibility of all.

\section{Disadvantages}

1) The system works only in the connectivity of the internet as the latest data from the load cell needs to be updated in the database which will calculate the factors such as limit reached, exceeded limit over the permitted limit and the amount of penalty charged.

2) The system may lead to a malfunction in case any one of the component stops working properly and will lead to discomfort of the user as system does not have a standby system to the main system.

\section{Conclusions and Recommendation}

The targeted waste is controlled at the society level which is the major contributor to waste generation and is often left unnoticed by the major waste management regulatory bodies. The project successfully reduced garbage production. Even this system will help the management bodies to take calculative measure for waste disposal as they have actual figures at hand.

The industries and societies that are generating waste more than allowed by the regulatory bodies will have to pay penalties for the excessive waste generated. The revenue generated can be used for proper disposal of the excess waste. The duty of waste management does not remain the concern of only the waste management bodies but also to distribute among the people of the region.

\section{Acknowledgements}

We sincerely thank the Director, Joint Director, Principal, Army Institute of Technology for their constant guidance and motivation to publish the paper.

\section{References}

[1] Zhu Minghua, Fan Xiumin, Alberto Rovetta, Municipal Solid Waste Management in Pudong New Area, China, Waste Management, Vol 29, 2008, 1277-33.

[2] Sufian, M.A. and Bala, B. K. Modeling of Urban Solid Waste Management System: The Case of Dhaka City", Waste Management, Vol 27, Issue 7, 2007, 858-868.

[3] G. Priya, Bhanu and Kumar, R. Santhosh. Smart Garbage Collecting Bin for Municipal Solid Waste", International Journal of Modern Trends in Engineering and Science, Vol 3, Issue 3, 2016, 10-18.

[4] Prakash Tambare and Prabu Venkatachalam, IoT Based Waste Management for Smart City,International Journal of Innovative Research in Computer and Communication Engineering, Vol 4, Issue 2, 2016, 1267-1274.

[5] Chitluri Sai Srikanth, Tadivaka Bhupathi Rayudu, Javvaji Radhika, Raju Anitha, Smart Waste Management Using Internet-of-Things", International Journal of Innovative Technology and Exploring Engineering, Vol 8, Issue 9, 2019,2518-2522,

[6] Krishna Nirde, Prashant Mulay and Uttam M. Chaskar, IoT Based Solid Waste Management System for Smart City, International Conference on Intelligent Computing and Control Systems, 2017, 666-669. 
[7] Shamin, N. Raghavendran, R and Kamalesh Prakash, Smart Garbage Segregation \& Management System Using Internet of Things(IoT) \& Machine Learning, 1st International Conference on Innovations in Information and Communication Technology, 2019.

[8] J.C.S. Carvalho, A.R. Rocha, F.R.C Sousa, A.B.B. Torres and J. N. de Souza, "Management of Multiple Applications for Shared Sensor and Actuators Networks", IEEE Latin America Transactions, Vol 14, Issue 10, 2016, 4358-4366.

[9] Ayesha Habib, M. Ali Afzal, Haleema Sadia, Yasar Amin and Hannu Tenhunen, Chipless RFID Tag for IoT Applications,, IEEE 59th International Midwest Symposium on Circuits and Systems, 2016.

[10] Kodwo Miezah, Kwasi Obiri-Danso, Zsofia Kadar, Bernard Fei-Baffoe and Moses Y.Mensah, Municipal Solid Waste Characterization and Quantification as a Measure Towards Effective Waste Management in Ghana, Waste Management, Vol 46,2015, 15-27.

[11] S. Loganayagi, and C.Jeyabharathi "Development of an Iot System for Efficient Classification and Management of Solid Waste in Indian Cities- A Research", International Journal of Innovative Technology and Exploring Engineering, Vol 8, Issue 12, 2019, 1221-1230.

[12] Rajkumar Joshi, Sirajuddin Ahmed and Carla Aparecida Ng, "Status and Challenges of Municipal Solid Waste Management in India: A Rreview”, Cogent Environmental Science Vol.2, Issue 1, 2016, 1-18.

[13] R. K. Kodali , V. S. K. Gorantla, Smart Solid Waste Management, 3rd International Conference on Applied and Theoretical Computing and Communication Technology, 2017, 200- 204.

[14] L. Michelle Goris, M. T. Harish and R. R. Bhavani, A System Design for Solid Waste Management: A Case Study of an Implementation in Kerala, IEEE Region 10 Symposium, pp. 1- 5, 2017.

*Corresponding author.

E-mail address: ashwinipatil_18977@aitpune.edu.in/swatijha_16365@aitpune.edu.in/umakumari_17918@aitpune.edu.in 